\title{
Production and Price Relationship of Ginger (Zingiber officinale) in Bangladesh: A Distributed Lag Model
}

\author{
Md. Kamrul Hasan ${ }^{1}$, Md. Mojammel Haque ${ }^{2} *$ and Md. Golam Rabbani ${ }^{3}$ \\ ${ }^{1}$ Spices Research Centre, Bangladesh Agricultural Research Institute, Bogra, Bangladesh \\ ${ }^{2}$ Graduate Training Institute, Bangladesh Agricultural University, Mymensingh, Bangladesh \\ ${ }^{3}$ Department of Economics, Hajee Mohammad Danesh Science and Technology University, \\ Dinajpur, Bangladesh \\ *Corresponding author and Email:mmh.gti@bau.edu.bd
}

Received: 01 September 2016

Accepted: 12 June 2017

\begin{abstract}
The study aimed at analyzing the fluctuation, and production-price relationship of ginger in Bangladesh. Nineteen years (1975 to 2013) time series data of area, production and prices of ginger, collected from Bangladesh Bureau of Statistics were used to analyze the simplest method for fluctuation, and the Koyck model of distributed lag. The extent of annual price fluctuation of ginger ranged between -50 to 63 percent, while the fluctuation of area, production and yield ranged between-5 to $13,-17$ to 22 and -20 to 11 percent, respectively. The study revealed that ginger production in Bangladesh had been influenced by the average price lag value formed in the market. The most striking result of the study was that the time required to get an effect on ginger production for the changes of ginger prices in Bangladesh was 19.83 years. This result shows that the farmers are very enthusiastic for growing ginger, the widely grown major spice crop. The correlation/regression coefficients indicated that the changes in lag values of the prices had a positive influence on production. It may be recommended that to keep the ginger price fluctuation under control, sustainable ginger farming and establishment of an efficient marketing organization is necessary.
\end{abstract}

Keywords: Ginger, production, price, distributed lag model.

\section{Introduction}

Cereals, tubers, fruits, vegetables, spices crops etc. are the main agricultural enterprises in Bangladesh. Ginger (Zingiber officinale) is one of the most common and popular spices, which has widely use in Bangladesh. However, the price fluctuation of ginger is relatively high (BBS 2015). However, there is no effective organization in the production and marketing of ginger in Bangladesh. Price of ginger can be controlled by maintaining it's supply. In the other way, fluctuations of ginger prices result the fluctuation of its production. So, farmers have to aware of market prices to make their production plan accordingly. Prices in the market are formed based on supply and demand principles rather than production costs. Establishing the interaction between agricultural production and price by a distributed lag model, such a model can significantly contribute to the literature.

The infrastructure facilities development in our country is still lagging behind. Transportation 
facilities, storage facilities, price control, regulated marketing system, price fluctuations etc. usually influence farmers for allocating land for different crops. Uncertainty of these factors is the main reasons for not obtaining expected price of the product (Motin et al., 2007). Ginger is one of the highest price fluctuated crops in Bangladesh, hence faces the highest risk and uncertainty. Therefore, proper production prediction is difficult.

Most of the farmers are illiterate or less literate and also they are not well organized therefore can have control on input and product markets. All these factors make ginger price uncertainties. Farmers consider the previous years' price for making their production plan. Such a planning causes big price and production fluctuations in ginger markets. This is called Cobweb theory in economy literature, often encountered in agricultural production and has been the subject of the investigations about production amount and price relationships.

Because of this structural feature of ginger produces, relationship between the amount produced and the price can be studied using distributed lag model. In the regression models in which time series data were used, if the model uses not only the present values but also the delayed past values of the defining variable, this model is defined as distributed lag model (Gujarati, 2005). Two major problems arise in distributed lag models. One of them is multi colinearity and the other is the increasingly lowered degrees of freedom as lag length increases. In order to overcome these problems, Koyck model has been developed for the estimation of parameters in distributed lag models.

In a study conducted by Yurdakul (1998) in Turkey, relationship between the production and price of cotton crop during 1985-1997 was studied using Koyck approach. In another study by Dikmen (2005), production and price relationship for tobacco crop in 1982-2003 periods was analyzed using Koyck model.
Eraktan et al. (2004) used Koyck model to investigate the relationship between Direct Income Support, a financial support paid by government to the farmers based on their agricultural land in Turkey, and value added produced. The study by Erdal (2006) dealt with the production and price in tomato crop in 19752004 period using Koyck approach. Another study by Ozcelik and Ozer (2006) studied wheat production and price relationship in 1973-2004 period using Koyck approach. Study conducted by Erdal and Erdal (2008) analyzed the relationship between dry onion production and price in 1975-2006 period via Koyck approach.

The research work has not so far been conducted on ginger crop in Bangladesh by using Koyck model. Therefore, the study was undertaken to aim at studying the price fluctuation and, the production amount and price relationship of ginger, a staple spices to a large extent in Bangladesh, using Koyck model.

\section{Objectives of the study}

The overall objective of the study was to determine production and price relationship of ginger in Bangladesh. The specific objectives of the study were: to identify the price, area, production and yield fluctuation of ginger; and to determine the price and production relationship of ginger.

\section{Materials and Methods}

Time series data (1975 to 2013) collected from Bangladesh Bureau of Statistics were used to estimate the production and prices relationship of ginger. These data, arranged yearly, which were subjected to regression analyses using Koyck model, one of the distributed lag models. Using same data fluctuation of price, area, production and yield of ginger were estimated. Random price fluctuation of ginger was measured by using 3 years moving average.

\subsection{Analytical technique}

The following analytical techniques were used for the study: 


\section{A. Fluctuation in price, area, production and yield}

The inter year fluctuation in prices were estimated by the simplest method as percentage change in price year by year. It is estimated as

$$
\Delta \mathrm{P}_{\mathrm{t}}=\frac{\mathrm{P}_{\mathrm{t}}-\mathrm{P}_{\mathrm{t}-1}}{\mathrm{P}_{\mathrm{t}-1}} \times 100
$$

Where, $\Delta \mathrm{P}_{\mathrm{t}}=$ Percentage change of price in year $\mathrm{t}$ over the last period (year), $\mathrm{P}_{\mathrm{t}}=$ Current year's price in year $\mathrm{t}, \mathrm{P}_{\mathrm{t}-1}=$ Previous year's price in year $\mathrm{t}-1$.

\section{B. Distributed lag model}

$$
Y_{t}=\alpha+\beta_{0} X_{t}+\beta_{1} X_{t-1}+\beta_{2} X_{t-2}+\ldots . .+\beta_{k} X_{t-k}+u_{t}
$$

Where, $Y_{t}$ is ginger production in period $t, X_{t}$ is ginger price in period $t$ and $X_{t-1}$ is ginger price in one period earlier than $t$.

\section{Koyck model}

$\mathrm{Y}_{\mathrm{t}}=\alpha(1-\lambda)+\beta_{0} \mathrm{X}_{\mathrm{t}}+\lambda \mathrm{Y}_{\mathrm{t}-1}+\mathrm{v}_{\mathrm{t}}$

\section{Results and Discussion}

Price fluctuation, and production and price relationship of ginger and are discussed in the following sub-sections.

\subsection{Estimation of fluctuation}

The extent of annual price fluctuation of ginger was identified which was between (-)50 to 63 percent while the extent of fluctuation of area, production and yield ranged between (-)5 to 13, (-)17 to 22 and (-)20 to 11 percent respectively during the study period. Price has fluctuated more than area, production and yield of ginger fluctuation. The extreme fluctuation of price took place in the year 2004-05 and 2011-12due to lower production resulted in lower supply of ginger in the market (Table 1).
Excessive fluctuation of area and production of ginger in Bangladesh occurred in 2007-08 (Table 1). This was mainly due to getting higher price in the previous two years tends to the farmer to increases ginger cultivation. Yield variability was caused by weather fluctuation and also for the insect and pest infestation.

Average annual variability or random fluctuation of ginger prices was estimated; where 11 observations were found above the trend line (three years moving average) and 15 observations were found below the trend line out of 26 observations. The extent of random fluctuation was lower than the extent of annual fluctuation (Table 2). Lower price during the current year adversely affect next year's production and this uncertainty in supply causes price to be fluctuated to a great extent.

\subsection{Estimation of the relationship between ginger prices and production}

In order to determine the relationship between ginger prices and production at the studied period, a correlation analysis was performed. Correlation coefficient of 0.79 is indicating a high level of relationship between the two variables. This result indicates that production amount and price relationship can be studied using Koyck model.

Distributed lag model was formed as follows:

$\mathrm{Q}_{\mathrm{t}}=\alpha+\beta_{0} \mathrm{P}_{\mathrm{t}}+\beta_{1} \mathrm{P}_{\mathrm{t}-1}+\beta_{2} \mathrm{P}_{\mathrm{t}-2}+\ldots \ldots \ldots .+\beta_{\mathrm{k}} \mathrm{P}_{\mathrm{t}-\mathrm{k}}+$ $\mathrm{u}_{\mathrm{t}}$

In the model, $\mathrm{Q}_{\mathrm{t}}$ is ginger production (ton) in period $t, P_{t}$ is ginger price in period $t(T k / t o n)$. In order to form Koyck model, it is necessary to determine lag value of ginger price series lag length.

In a distributed lag model, Schwarz information criterion (SIC) is used to determine the lag length (Dikmen, 2005). 
Table 1. Fluctuation of price, area, production, yield of ginger in Bangladesh for the period of 1985-86 to $2012-13$

\begin{tabular}{lcccc}
\hline Year & Price $(\%)$ & Area $(\%)$ & Production $(\%)$ & Yield (\%) \\
\hline $1985-86$ & - & - & - & - \\
$1986-87$ & 49.14 & -2.49 & 0.43 & 2.99 \\
$1987-88$ & 25.52 & 1.61 & -1.90 & -3.45 \\
$1988-89$ & -24.08 & 5.11 & -0.74 & -5.57 \\
$1989-90$ & -6.75 & 5.70 & 8.65 & 2.79 \\
$1990-91$ & -4.21 & 0.73 & -0.35 & -1.07 \\
$1991-92$ & -35.82 & 0.55 & -2.68 & -3.21 \\
$1992-93$ & 58.78 & 0.11 & 0.98 & 0.86 \\
$1993-94$ & 23.10 & -0.66 & -4.24 & -3.61 \\
$1994-95$ & 27.64 & -1.61 & -1.74 & -0.13 \\
$1995-96$ & 0.84 & -0.23 & -1.20 & -0.97 \\
$1996-97$ & -38.47 & 0.12 & -0.60 & -0.72 \\
$1997-98$ & 12.92 & 0.21 & -0.22 & -0.42 \\
$1998-99$ & 32.11 & -0.53 & -1.55 & -1.03 \\
$1999-00$ & 29.62 & 0.47 & 0.53 & 0.05 \\
$2000-01$ & -17.50 & 5.60 & 9.60 & 3.80 \\
$2001-02$ & -17.09 & 2.77 & 1.70 & -1.04 \\
$2002-03$ & 12.36 & 1.00 & 0.40 & -0.59 \\
$2003-04$ & 31.75 & 4.54 & 12.52 & 7.63 \\
$2004-05$ & 62.74 & -2.56 & 2.53 & 5.22 \\
$2005-06$ & -9.41 & 4.28 & 15.57 & 10.83 \\
$2006-07$ & -46.59 & 3.70 & 10.91 & 6.96 \\
$2007-08$ & 26.16 & 12.93 & 21.67 & 7.74 \\
$2008-09$ & 42.24 & -4.24 & -5.76 & -1.59 \\
$2009-10$ & 58.57 & 0.54 & 3.08 & 2.52 \\
$2010-11$ & 14.64 & 0.55 & -0.62 & -1.16 \\
$2011-12$ & -50.16 & -4.56 & -3.09 & 1.54 \\
$2012-13$ & 58.58 & 2.76 & -17.45 & -19.67 \\
\hline Extent of fluctuation & -53 & to 13 & -17 to 22 & -20 to 11 \\
\hline & & & &
\end{tabular}


Table 2. Random fluctuation of harvest price of ginger for the period from 1985-86 to 2012-13 in Bangladesh

\begin{tabular}{|c|c|c|c|}
\hline Year & Harvest price (Tk/ton) & $\begin{array}{c}3 \text { years moving } \\
\text { average }\end{array}$ & $\begin{array}{l}\text { Percent of deviation } \\
\text { from actual price }\end{array}$ \\
\hline $1985-86$ & 11108 & - & - \\
\hline 1986-87 & 16566 & 16156 & 2.54 \\
\hline $1987-88$ & 20793 & 17715 & 17.38 \\
\hline 1988-89 & 15786 & 17100 & -7.68 \\
\hline 1989-90 & 14720 & 14869 & -1.00 \\
\hline 1990-91 & 14100 & 12623 & 11.70 \\
\hline 1991-92 & 9050 & 12507 & -27.64 \\
\hline 1992-93 & 14370 & 13703 & 4.86 \\
\hline 1993-94 & 17690 & 18213 & -2.87 \\
\hline 1994-95 & 22580 & 21013 & 7.46 \\
\hline 1995-96 & 22770 & 19787 & 15.08 \\
\hline 1996-97 & 14010 & 17533 & -20.10 \\
\hline 1997-98 & 15820 & 16910 & -6.45 \\
\hline 1998-99 & 20900 & 21270 & -1.74 \\
\hline 1999-00 & 27090 & 23447 & 15.54 \\
\hline 2000-01 & 22350 & 22657 & -1.35 \\
\hline 2001-02 & 18530 & 20567 & -9.90 \\
\hline 2002-03 & 20820 & 22260 & -6.47 \\
\hline 2003-04 & 27430 & 30963 & -11.41 \\
\hline 2004-05 & 44640 & 37503 & 19.03 \\
\hline 2005-06 & 40440 & 35560 & 13.72 \\
\hline 2006-07 & 21600 & 29763 & -27.43 \\
\hline 2007-08 & 27250 & 29203 & -6.69 \\
\hline 2008-09 & 38760 & 42490 & -8.78 \\
\hline 2009-10 & 61460 & 56893 & 8.03 \\
\hline 2010-11 & 70460 & 55680 & 26.54 \\
\hline 2011-12 & 35120 & 53757 & -34.67 \\
\hline $2012-13$ & 55692 & - & - \\
\hline Range of fluctuation & - & - & -35 to 27 \\
\hline
\end{tabular}


Schwarz proposes reduction of Equation (5) to the lowest:

$\mathrm{SIC}=\ln \sigma^{2}+\mathrm{m} \ln n$

Here, $\sigma^{2}$ is the highest probability estimate of $\sigma^{2}$ $=(\mathrm{RSS} / n), m$ is length of the lag, $n$ is the number of observations and RSS is the residual sum of square. In summary, a regression model is used along with some lag values $(=m)$, and $m$ value that makes the value of Schwarz criterion the lowest is selected (Gujarati, 2005). At this stage, without making any limitation to the form of the distributed lag, a very large $\mathrm{k}$ value length of the lag is used at the start. Then, when the duration of lag is shortened, whether the model goes wrong is checked (Davidson and Mackinnon, 1993).

Values for Schwarz criterion determined at different lag lengths for Equation (5) is given in Table3. As can be seen from Table 3, the lowest Schwarz value (21.35) was obtained from lag length $K=1$. Thus, effect of ginger prices on ginger production is zero after one year. According to the determined lag lengths, the relationship between ginger production and price has been estimated using the classical least squares method given in Equation (4). The results of the model are given in Table 4.

According to the results in Table4, ginger prices in the period $\mathrm{t}$ and one period earlier ( $\mathrm{t}-1)$ positively affected the ginger production while ginger prices two periods earlier ( $\mathrm{t}-2)$ negatively affected the production. Partial regression coefficients in the model except $\left(\beta_{0}\right)$ are statistically insignificant. Model, as a whole, is also statistically significant as well. Coefficient of multiple determination of the model is 0.75 , which means that 75 percent of the changes in ginger production can be explained through changes in ginger price and its distributed lag values.

Although statistically significant as a whole, the model has to be questioned in terms of reliability for two points related to distributed lag models. The first is the multiple relationship problems as a result of the fact that lag values of price variable was used in the model. The second problem is the loss of observations occurred in lag value set. If the number of data in formed series is not large, estimated values can be inconsistent due to lags.

In order to overcome these two major problems, estimations were made using Koyck model. Estimation results of regression equation are in Table 4 while, Koyck model estimation results are in Table 5.

The Koyck model estimation results in Table 5 shows that one taka increase in ginger price increase the ginger production by 0.005 tonnes. This coefficient was statistically significant. An increase of one tonne of ginger production in the previous period increased the ginger production by 0.952 tonnes. According to mean lag number, the time required for changes in ginger prices to have a significant and detectable effect on ginger production was 19.83 years. This result shows that Bangladeshi farmers, who most often grow ginger as a staple spice crop, are very enthusiastic in growing ginger.

Table 3. Lag length values based on Schwarz criterion

\begin{tabular}{ccc}
\hline Sl. No. & Lag length & Schwarz values \\
\hline 1. & $\mathrm{~K}=1$ & 21.35 \\
2. & $\mathrm{~K}=2$ & 24.85 \\
3. & $\mathrm{~K}=3$ & 28.18 \\
4. & $\mathrm{~K}=4$ & 31.61 \\
5. & $\mathrm{~K}=5$ & 34.99 \\
\hline
\end{tabular}


Table 4. The results of distributed lag model

\begin{tabular}{|c|c|c|c|c|c|}
\hline \multirow[t]{3}{*}{ Items } & \multicolumn{5}{|c|}{$\mathrm{Q}_{\mathrm{t}}=28660.69+0.172 \mathrm{P}_{\mathrm{t}}+0.46 \mathrm{P}_{\mathrm{t}-1}-0.321 \mathrm{P}_{\mathrm{t}-2}+0.607 \mathrm{P}_{\mathrm{t}-3}$} \\
\hline & \multicolumn{5}{|c|}{ Lag length } \\
\hline & Constant & $\mathrm{t}$ & $\mathrm{t}-1$ & $\mathrm{t}-2$ & $\mathrm{t}-3$ \\
\hline Coefficient & 28660.69 & 0.172 & 0.460 & -0.321 & 0.607 \\
\hline t-values & 12.730 & 1.264 & 2.426 & -1.281 & 2.564 \\
\hline Probability & 0.000 & 0.216 & 0.022 & 0.210 & 0.016 \\
\hline \multicolumn{6}{|c|}{$\mathrm{R}^{2}=0.75 \mathrm{~F}=22.702 \mathrm{P}=000 \mathrm{DW}=0.704$} \\
\hline
\end{tabular}

Table 5. The results of Koyck model

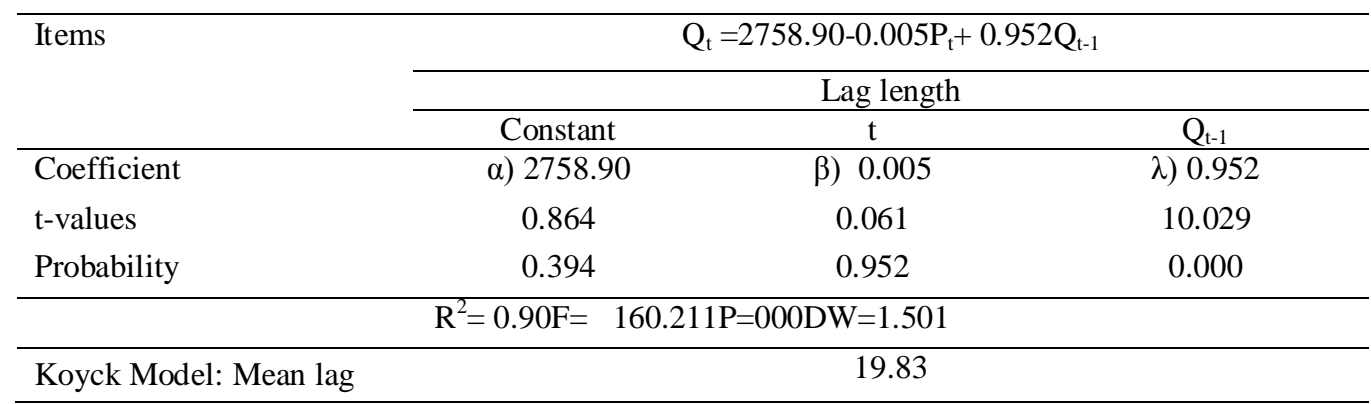

Note: $\mathrm{Q}_{\mathrm{t}}$ is ginger production in period $\mathrm{t}, \mathrm{P}_{\mathrm{t}}$ is ginger price in period $\mathrm{t}$ and $\mathrm{Q}_{\mathrm{t}-1}$ is ginger production in one period

earlier than t. Mean lag $=\frac{\lambda}{1-\lambda}$

Different crops the time required for the prices to have considerable changes is 1.19 years for tobacco (Dikmen, 2005), 18 years for tomato (Erdal, 2006), 0.83 years for wheat (Ozcelik and Ozer, 2006) and 1.19 years for dry onion (Erdal and Erdal, 2008) in Turkey.

In Koyck model,

$\mathrm{Q}_{\mathrm{t}}=\alpha+\beta_{0} \mathrm{P}_{\mathrm{t}}+\lambda \mathrm{Q}_{\mathrm{t}-1}+\mathrm{u}_{\mathrm{t}}$ and $\beta_{\mathrm{k}}=\lambda^{\mathrm{k}} \beta_{0}$

Since $0<\lambda<1$, using the following calculations Equation (4) is reached;

$\beta_{0}=\lambda^{0} \beta_{0}=(0.952)^{0}(0.005)=0.005$

$\beta_{1}=\lambda^{1} \beta_{0}=(0.952)^{1}(0.005)=0.0048$

$\beta_{2}=\lambda^{2} \beta_{0}=(0.952)^{2}(0.005)=0.0045$

$\beta_{2}=\lambda^{3} \beta_{0}=(0.952)^{3}(0.005)=0.0043$

$\alpha_{0}=\alpha /(1-\lambda)=2748.90 /(1-0.952)=57268.75$

When the regression formulae derived from Koyck model is rewritten using this results, equation (3) is obtained;

$$
\begin{aligned}
& \mathrm{Q}_{\mathrm{t}}=57268.75+0.005 \mathrm{P}_{\mathrm{t}}+0.0048 \mathrm{P}_{\mathrm{t}-1}+0.0045 \mathrm{P}_{\mathrm{t}-2} \\
& +0.0043 \mathrm{P}
\end{aligned}
$$

In Equation (6), which represents a distributed lag model derived from Koyck model, it is seen that lag ginger prices have a decreasing effect on ginger production, since $0<\lambda<1$. Decreasing effects of lag price parameters result from the fact that $\lambda$ coefficient exerts an effect which was limited in the model.

According to Equation (6), a one-unit increase in ginger prices in Bangladesh increased the production by 0.005 tons in that year while, a one-unit increase in the previous year increased the production by 0.0048 tons. In addition, a one-unit price increase two years ago increased the production by 0.0045 tons. On the other hand, a one-unit price increase three years ago increased the production by 0.0043 tons. Although the changes in lag values of the prices 
had a positive influence on production, this influence was getting smaller.

\section{Conclusions and Recommendation}

The study revealed that price fluctuated more than area, production and yield of ginger in Bangladesh as a whole. The extent of random fluctuation was lower than the extent of annual fluctuation. Lower price during the current year adversely affect the next year's production and this uncertainty in supply causes price to be fluctuated to a great extent. The calculated lag length was 1 , indicating that ginger production was influenced by the prices of upto past one year. It is evident that each additional lag value results in a smaller effect on ginger production. Considering the average lag number, it can be stated that ginger producers in Bangladesh are very enthusiastic for growing ginger. However, price uncertainties resulted in fluctuations in the production of this crop in Bangladesh.

For sustainable ginger farming in Bangladesh, establishment of an efficient marketing organization is a necessity. At this point, policies are needed to be developed for efficient, profitable and sustainable ginger farming. Thus, price uncertainties that the producers face can be overcome, and contribution of this major spice crop to national economy can be increased.

\section{References}

Alt, F. 1942. Distributed lags. Econometrica, 10: 113-128.

BBS. 1975 to 2015. Statistical Yearbook of Bangladesh. Bangladesh Bureau of Statistics, Planning Division, Ministry of Planning, Dhaka.

Bonde, S.R. and Prakash, H.2006. Ginger Cultivation in India. National Horticultural Research and Development Foundation, Nashik, India.

Carrasco, M. 2002. Misspecified structural change, threshold, and markov-switching models. Journal of Econometrics, 109: 239-273.

Davidson, R. and Mackinnon, J.G. 1993. Estimation and inference in econometrics, New York, Oxford university pres., ISBN 0-19-506011-3, 675-676 pp.

Davies, R.B. 1987. Hypothesis testing when a nui-An Analysis of Production and Price Relationship for Ginger in Turkey: A Distributed Lag Model Application 249 sance parameter is present only under the alternative. Biometrika, 64:247-254.

Dikmen, N. 2005. The relationship tobacco and price with koyck-almon approach, VII. National econometrics and statistical symposium, 26-27 May, Ýstanbul University. Available at http:// www.ekonometridernegi.org/bildiriler/o1 6s1.pdf.

Eraktan, G., Abay, C. Miran, B. and Olhan, E. 2004. Direct income support and results in promote of agriculture in Turkey. Publication of Istanbul Chamber of Commerce, 53:68-71.

Erdal, G. and Erdal, H. 2008. The interaction between production and prices for dry onion. Journal of Agricultural Faculty of Gaziosmanpasa University, 25:33-39.

Erdal, G. 2006. The analysis of the relation between production and price in agricultural products with Koyck model (tomato case). Journal of Agric. Faculty of Gaziosmanpasa University, 23:17-24.

Franses, P.H. and Oest, R. 2004. On the econometrics of the Koyck model. Econometric Institute Report, Erasmus University Rotterdam.

Gujarati, D.N. 2005. Basic Econometrics. Fourth Edition, Tata McGraw-Hill Edition.

Hansen, B.E. 1996. Inference when a nuisance parameter is not identified under the null hypothesis. Econometrica, 64:413-430. 
Koyck, L.M. 1954. Distributed Lags and Investment Analysis. North Holland Publishing Company, Amsterdam, 21-50 pp.

Matin M.A., Hossain, M.A. and Alam, Q.M. 2007. Brinjal Marketing System in Selected Areas of Bangladesh. Research Report. Agricultural Economics Division, Bangladesh Agricultural Research Institute, Joydebpur, Gazipur.
Ozcelik, A. and Ozer, O.O. 2006. Analysis of Correlation of Wheat Production and Prices with Koyck Models in Turkey. Journal of the Agriculture Sciences of Ankara University, 12:333-339.

Yurdakul, F. 1998. The econometrics analysis of relationships between of cotton production and prices: Koyck-Almon approach. Journal of Faculty of Economics and Administrative Sciences of Cukurova University, 8:1. 